\title{
Double-blind comparison of aspirin and 4-(acetamido) phenyl-2-acetoxy-benzoate (benorylate) in rheumatoid arthritis
}

\author{
P. N. SPERRYN, ${ }^{*}$ E. B. D. HAMILTON, AND VALERIE PARSONS \\ Departments of Physical Medicine and Rheumatology and of Biochemistry, King's College Hospital, London
}

Preliminary studies in man of benorylate, 4-(acetamido)phenyl-2-acetoxy-benzoate, have shown that it has antipyretic actions (Weill, Gaillon, Rendu, and Lejeune, 1968; Alexander, Flahaut, Raveschot, Drykonigen, 1970) and an analgesic action significantly superior to placebo and in some instances superior to aspirin (Vialatel and Gaillon, 1968; Hart and Nicholson, 1971). In rheumatoid arthritis, Bain and Burt (1970) and Cardoe (1970) have shown that the drug is well tolerated and effective, although the results suggested that their initial dose of $4 \mathrm{~g}$. was inadequate.

The pharmacology of benorylate has been reported by Rosner, Malhie, and Mottot (1968) and the pharmacodynamics of the drug have been described by Robertson (1971). Benorylate is well absorbed when taken orally and unlike aspirin its absorption is not influenced by $\mathrm{pH}$. After absorption the molecule undergoes hydrolysis to provide salicylic acid (SA) and $n$-acetyl paraminophenol (NAPA). When compared with aspirin and paracetamol, the peak plasma concentrations of SA and NAPA are achieved later and more smoothly after benorylate administration. The plateau levels of SA and NAPA obtained after continuous medication are very similar with the three drugs. Excretion of metabolites occurs through the kidney ( 85 per cent. and faeces ( 15 per cent).

These findings, and the preliminary clinical results, suggested that benorylate merited further assessment in the treatment of rheumatoid arthritis.

\section{Method}

\section{Patients}

41 patients with classical or definite rheumatoid arthritis (Ropes, Bennett, Cobb, Jacox, and Jessar, 1959) entered the trial; 21 were to receive aspirin and 20 benorylate. Eight patients withdrew: two from each group because of indigestion, two in the benorylate group defaulted, and two in the aspirin group were withdrawn because of lack of analgesia. This left seventeen patients in the aspirin group and sixteen in the benorylate group. The two groups
(Table I) were found to be comparable for age, sex ratio, disease duration, presence of nodules and erosions, functional status, pain, morning stiffness, number of

Table I Comparability of the two treatment groups Differences not significant at the 5 per cent. level

\begin{tabular}{|c|c|c|}
\hline Dosage & $\begin{array}{l}\text { Aspirin } \\
(4 \mathrm{~g} .)\end{array}$ & $\begin{array}{l}\text { Benorylate } \\
(6 \mathrm{~g} .)\end{array}$ \\
\hline Total no. of patients & 17 & 16 \\
\hline Sex: $\mathbf{F}$ & $\begin{array}{r}13 \\
4\end{array}$ & $\begin{array}{r}13 \\
3\end{array}$ \\
\hline Mean age (yrs) & 56 & 59 \\
\hline $\begin{array}{l}\text { Duration of disease (yrs) } \\
\text { less than } 5 \\
5-15 \\
\text { more than } 15\end{array}$ & $\begin{array}{l}8 \\
7 \\
2\end{array}$ & $\begin{array}{r}10 \\
4 \\
2\end{array}$ \\
\hline $\begin{array}{c}\text { Functional status } \\
\text { Grade } \text { I }_{\text {II }} \\
\text { III }\end{array}$ & $\begin{array}{l}6 \\
7 \\
3 \\
1\end{array}$ & $\begin{array}{l}6 \\
8 \\
1 \\
1\end{array}$ \\
\hline $\begin{array}{l}\text { Initial pain severity } \\
\text { Nil } \\
\text { Mild } \quad(0) \\
\text { Moderate (2) } \\
\text { Severe } \quad \text { (3) }\end{array}$ & $\begin{array}{l}0 \\
0 \\
9 \\
8\end{array}$ & $\begin{array}{l}0 \\
0 \\
6 \\
9\end{array}$ \\
\hline $\begin{array}{l}\text { Median no. inflamed joints } \\
\text { No. patients with nodules } \\
\text { No. patients with erosions }\end{array}$ & $\begin{array}{r}13 \\
6 \\
17\end{array}$ & $\begin{array}{r}12 \\
5 \\
14\end{array}$ \\
\hline $\begin{array}{l}\text { Mean duration morning stiffness } \\
\text { (hrs) }\end{array}$ & $3 \cdot 2$ & $3 \cdot 6$ \\
\hline Articular Index (median score) & 12 & 11 \\
\hline $\begin{array}{l}\text { Initial grip strength (mm. Hg) } \\
\text { Right } \\
\text { Left }\end{array}$ & $\begin{array}{l}106 \\
114\end{array}$ & $\begin{array}{l}71 \\
69\end{array}$ \\
\hline $\begin{array}{l}\text { Mean total ring size (mm.) } \\
\text { Right } \\
\text { Left }\end{array}$ & $\begin{array}{l}290 \\
288\end{array}$ & $\begin{array}{l}289 \\
283\end{array}$ \\
\hline
\end{tabular}


inflamed joints, ring size, and articular index (Ritchie, Boyle, McInnes, Jasani, Dalakos, Grieveson, and Buchanan, 1968). The initial grip strength was slightly less in the benorylate group.

Patients were excluded if they had received steroids, gold, or anti-malarial drugs within the previous year, or had a definite history of aspirin intolerance.

\section{Dosage}

The drugs were presented as identical tablets and the patients were treated according to a predetermined random code. The daily dose of aspirin was $4 \mathrm{~g}$. and of benorylate $6 \mathrm{~g}$. The higher dosage of benorylate as compared with aspirin was chosen because absorption studies had previously shown that a dosage of $6 \mathrm{~g}$. of benorylate was approximately equivalent to administering a combined dosage of $3 \mathrm{~g}$. aspirin and $3 \mathrm{~g}$ paracetamol (Robertson, 1971). No other analgesics or anti-inflammatory drugs were permitted and physiotherapy was withheld for the duration of the trial. The ferric chloride test was performed at each attendance to check that the drugs were being taken.

\section{Assessment}

A preliminary assessment was made and the patient was given inert placebo tablets identical in appearance with the active drugs. Initially the placebo was given for 7 days, but because of the frequency of distressing relapses of joint pains this was reduced to the 48 -hr period before the second assessment.

After the initial visit further assessments were made after 1 week, when the patient was started on either aspirin or benorylate, 5 weeks, 9 weeks, and at the end of the trial at 13 weeks. The clinical parameters recorded at each attendance are listed in Table I.

\begin{tabular}{|c|c|}
\hline $\begin{array}{l}\text { FUNCTIONA } \\
\text { This was clas }\end{array}$ & $\begin{array}{l}\text { L STATUS } \\
\text { sified as follows: }\end{array}$ \\
\hline Grade I & Fit for all activities \\
\hline Grade II & $\begin{array}{l}\text { Moderate restriction, no dependence on } \\
\text { others }\end{array}$ \\
\hline Grade III & $\begin{array}{l}\text { Marked restriction, some dependence on } \\
\text { others }\end{array}$ \\
\hline Grade IV & $\begin{array}{l}\text { Confined to bed or chair, completely } \\
\text { dependent }\end{array}$ \\
\hline
\end{tabular}

PAIN

This was graded 1-mild, 2-moderate, and 3-severe, by the patients' subjective assessment.

\section{ARTICULAR INDEX}

The index used was modified from the method of scoring on a four-point scale (0-1-2-3) the pain on palpating the joints, as described by Ritchie and others (1968). We found it unreliable in some cases of severe inflammation to differentiate between the ankle, talo-calcaneal, and midtarsal joints and preferred to count these together as one unit.

\section{LABORATORY INVESTIGATIONS}

These included a full blood count and erythrocyte sedimentation rate. Total and heat-labile serum lactate dehydrogenase (LDH) was measured by the method of Henry, Chiamori, Golub, and Berkman (1960), using an LKB Reaction Rate Analyser, the heat-labile fraction being inactivated by heating for $30 \mathrm{~min}$. at $57^{\circ} \mathrm{C}$.
$\alpha$-Hydroxybutyrate dehydrogenase $(\alpha \mathrm{HBDH})$ was measured by the method of Wootton (1964).

Blood urea, serum bilirubin, and total protein estimations were made by standard Technicon Auto Analyser methods.

Serum proteins were separated by electrophoresis on cellulose acetate.

\section{Results}

The clinical results of the trial are summarized in Table II.

Both drugs produced an equal reduction in the overall pain level at the end of the study $(P<0.05)$. At the monthly assessments the benorylate group showed a progressive improvement in the total number of inflamed joints and in the articular index; after 3 months this improvement was significantly greater than that in the aspirin group. Improvement in grip strength and in the duration of morning stiffness occurred in both groups, but, because of the large standard error, differences between the drugs did not attain statistical significance. Throughout the study there were no significant changes in functional status or digital ring size in either group.

\section{LABORATORY ANALYSES}

Haematology Throughout the period of the tria there were no consistent changes in the measurements of erythrocyte sedimentation rate, haemoglobin white cell, and platelet counts.

Biochemistry The serum enzyme investigations (total and heat-labile LDH and $\alpha \mathrm{HBDH}$ ) were performed as an indication of tissue damage (particularly hepatic tissue) or of in vivo haemolysis. They showed no regular pattern of change during the trial. The total LDH activities were raised in six patients from each group before participating in the trial, probably because of the rheumatoid arthritis itself or previous treatment. In all but one of these (a patient in the benorylate group), the levels returned to normal during the trial, although in some subjects there were temporary increases in total LDH activity. $\alpha \mathrm{HBDH}$ usually paralleled total LDH. Heat-labile LDH remained within normal limits in most patients, but increased after 4 weeks of treatment in five patients in the aspirin group.

One patient in the benorylate group had a raised heat-labile LDH, the total LDH and $\alpha \mathrm{HBDH}$ being normal.

In one patient in the aspirin group, a raised LDH and $\alpha H B D H$ with lowered heat-labile LDH suggested haemolysis or myocardial infarction, but there was no clinical evidence of either condition. Schumm's test was negative and electrophoresis revealed an increase in LDH isoenzymes I and II consistent with either condition.

No significant changes were found in the protein electrophoresis or blood urea. 
Table II Improvement in disease state as compared with initial assessment

\begin{tabular}{|c|c|c|c|}
\hline Dosage & Aspirin & Benorylate & $\begin{array}{l}\text { Significance of } \\
\text { difference between } \\
\text { drug groups }\end{array}$ \\
\hline $\begin{array}{l}\text { Overall pain level at week } 13 \\
\text { Better } \\
\text { Unchanged } \\
\text { Worse }\end{array}$ & $\begin{array}{r}10 \\
5 \\
2\end{array}$ & $\begin{array}{r}10 \\
4 \\
2\end{array}$ & $P>0.05$ \\
\hline $\begin{array}{l}\text { Total no. inflamed joints } \\
\text { (Mean } \pm \text { S.E. of reduction) } \\
\text { Week } 5 \\
\text { Week } 9 \\
\text { Week } 13\end{array}$ & $\begin{array}{l}5 \pm 2 \\
3 \pm 3 \\
0 \pm 2\end{array}$ & $\begin{array}{l}6 \pm 2 \\
8 \pm 3 \\
9 \pm 3\end{array}$ & $P<0.02$ \\
\hline $\begin{array}{l}\text { Total articular index score } \\
\text { (Mean } \pm \text { S.E. of reduction) } \\
\text { Week } 5 \\
\text { Week } 9 \\
\text { Week } 13\end{array}$ & $\begin{array}{l}5 \pm 1 \\
2 \pm 2 \\
2 \pm 1\end{array}$ & $\begin{array}{l}4 \pm 2 \\
5 \pm 2 \\
7 \pm 2\end{array}$ & $P<0.05$ \\
\hline $\begin{array}{l}\text { Mean grip strength } \\
\text { (Mean } \pm \text { S.E. of percentage improvement) } \\
\text { Right hand } \\
\text { Week } 5 \\
\text { Week } 9 \\
\text { Week } 13 \\
\end{array}$ & $\begin{array}{l}11 \pm 12 \\
6 \pm 10 \\
8 \pm 13 \\
\end{array}$ & $\begin{array}{l}36 \pm 18 \\
46 \pm 18 \\
34 \pm 14 \\
\end{array}$ & $P>0.05$ \\
\hline $\begin{array}{l}\text { Left hand } \\
\text { Week } 5 \\
\text { Week } 9 \\
\text { Week } 13\end{array}$ & $\begin{array}{l}6 \pm 11 \\
5 \pm 9 \\
8 \pm 8\end{array}$ & $\begin{array}{l}23 \pm 10 \\
35 \pm 13 \\
35 \pm 14\end{array}$ & $P>0.05$ \\
\hline $\begin{array}{l}\text { Duration of morning stiffness } \\
\text { (Mean } \pm \text { S.E. of reduction in duration (hrs)) } \\
\text { Week } 5 \\
\text { Week } 9 \\
\text { Week } 13\end{array}$ & $\begin{array}{l}1 \cdot 21 \pm 0.69 \\
1.91 \pm 0.91 \\
1 \cdot 10 \pm 0.64\end{array}$ & $\begin{array}{l}1 \cdot 12 \pm 0.96 \\
1.75 \pm 0.98 \\
1 \cdot 45 \pm 0.84\end{array}$ & $P>0.05$ \\
\hline
\end{tabular}

SIDE-EFFECTS (Table III)

There were fewer spontaneous complaints in the benorylate group than in the aspirin group. There was more indigestion in the aspirin group.

\section{Discussion}

The results of the present study have shown that benorylate is an effective analgesic for the treatment of active rheumatoid arthritis. A significant antiinflammatory effect, as measured by a reduction in the erythrocytic sedimentation rate after 4 weeks has been demonstrated by Haslock, Nicholson, and Wright (1971) and Franke and Manz (1972). Although we used the same daily dose of benorylate (6 g.), the present results have not confirmed their findings, but this may be due to the longer duration of the current study, as Franke and Manz (1972) found that the mean erythrocytic sedimentation rate had started to increase again after the fourth week. Hart and Huskisson (1972) suggested that a reduction in the circumference of the proximal interphalangeal joints was also a good assessment of anti-inflamma-

\section{Table III Side-effects of 3 months}

\begin{tabular}{|c|c|c|}
\hline Daily dosage & Aspirin $4 \mathrm{~g}$ & Benorylate $6 \mathrm{~g}$ \\
\hline $\begin{array}{l}\text { Total patients with side } \\
\text { effects, including side-effect } \\
\text { withdrawals }\end{array}$ & 15 & 9 \\
\hline $\begin{array}{l}\text { Indigestion, nausea, } \\
\quad \text { flatulence } \\
\text { Constipation } \\
\text { Drowsiness } \\
\text { Tinnitus } \\
\text { Macular rash } \\
\text { Miscellaneous }\end{array}$ & $\begin{array}{l}8 \\
4 \\
2 \\
1 \\
0 \\
\text { Itchy legs } 1 \\
\text { Nocturia } 1\end{array}$ & $\begin{array}{l}3 \\
2 \\
1 \\
0 \\
1 \\
\text { Sweating } 1 \\
\text { Nocturia } 1\end{array}$ \\
\hline Total & 17 & 9 \\
\hline
\end{tabular}

tory effect, but they warned that this reduction can usually be obtained in only a small number of patients. No significant change was found in the present study in either drug group, but the benorylate-treated group showed a significantly greater reduction in the number of inflamed joints and in the articular index 
than did the aspirin group. Both groups also experienced an improvement in grip strength and a reduction in the duration of morning stiffness.

Using total daily doses in excess of $5 \mathrm{~g}$., Boardman and Hart (1967) were able to demonstrate a measureable anti-inflammatory response with aspirin, but this dose is often too high to be tolerated by outpatients for long periods of time. For this reason we used a daily dose of $4 \mathrm{~g}$. aspirin, which is more commonly used in practice, and compared this with benorylate $6 \mathrm{~g}$. a day, a dose which had been shown by other workers to be effective in rheumatoid arthritis. For ease of administration benorylate is now usually prescribed as a suspension. This preparation of the drug was not available when the present study was started, but Robertson, Glynn, and Watson (1972) have found no difference in the plasma salicylate levels when comparable amounts of the drug are given as tablets or as a suspension.

At the dose of $6 \mathrm{~g}$., benorylate was well tolerated by the patients and gave rise to fewer side-effects than aspirin. This was most clearly seen with those sideeffects relating to the gastro-intestinal tractindigestion and nausea-which is in keeping with the findings of other authors. Cardoe (1970) and Franke and Manz (1972) found that faecal occult bleeding did not occur with benorylate therapy and a recent study by Cuddigan (1971) investigated this further.
Using the ${ }^{51} \mathrm{Cr}$ red cell tagging technique in a group of patients with rheumatoid arthritis, Cuddigan found that the mean daily blood loss during benorylate therapy ( $8 \mathrm{~g}$. daily) was less than $2 \mathrm{ml}$./day. When the same group of patients were given aspirin $(4 \cdot 8 \mathrm{~g}$. daily) the mean daily blood loss was approximately $5 \mathrm{ml}$.

\section{Summary}

A double-blind between-patient trial over 3 months to compare the effects of aspirin, $4 \mathrm{~g}$. daily, with benorylate, $6 \mathrm{~g}$. daily, was completed in 33 outpatients with rheumatoid arthritis.

Benorylate produced a greater reduction in the total number of inflamed joints and in the total articular index than aspirin, and in both groups there was a similar mean reduction of pain.

No significant changes were found in either group in functional status, duration of morning stiffness, total digital ring size, grip strength, or erythrocytic sedimentation rate. There were fewer side-effects with benorylate than aspirin, and markedly less indigestion.

We wish to thank the medical and nursing staff who helped with this trial and also Dr. P. A. Nicholson for his con-8 tinued assistance. We are grateful to Mrs. H. R. Lane B.Sc., A.I.S., for performing the statistical analysis.

\section{References}

Alexander, F., Flahaut, J., Raveschot, H., And Drykoningen, G. (1970) Brux. méd., 50, 439 (Etude de l'activité antipyrétique d'une nouvelle substance, le bénorylate, dans la clinique pédiatrique)

BaIn, L. S., AND BurT, R. A. P. (1970) Clin. Trials J., 7, 307 (The treatment of rheumatoid disease. A double-blind trial comparing buffered aspirin with benorylate)

Boardman, P. L., AND Hart, F. Dudley (1967) Brit. med. J., 4, 264 (Clinical measurement of the anti-inflammatory effects of salicylates in rheumatoid arthritis)

Cardoe, N. (1970) Clin. Trials J., 7, 313 (The treatment of rheumatoid disease. Preliminary assessment of a new drug: benorylate)

Cuddigan, J. H. P. (1971) 'VII European Rheumatology Congress': abstract No. 45/7 (Gastro-intestinal blood loss during benorylate therapy)

Franke, M., AND MANz, G. (1972) Curr. ther. Res., 14, 112 (Benorylate and indomethacin in the treatment of rheumatoid disease: a double-blind clinical trial)

HART, F. Dudley, AND Huskisson, E. C. (1972) Lancet, 1, 28 (Measurement in rheumatoid arthritis)

Hart, G., AND Nicholson, P. A. (1971) Clin. Trials J., 8, 51 (The analgesic activity of benorylate, aspirin, and placebo: a double-blind single-dose comparison)

Haslock, D. I., Nicholson, P. A., AND Wright, V. (1971) Clin. Trials J., 8, No 1, p. 43 ( A comparison of phenylbutazone and benorylate)

Henry, R. J., Chiamori, N., Golub, O. J. and Berkman, S. (1960) Amer. J. clin. Path., 34, 381 (Revised spectrophotometric methods for the determination of glutamic-oxalacetic transaminase, glutamic-pyruvic transaminase, and lactic acid dehydrogenase)

Ritchie, D. M., Boyle, J. A., McInnes, J. M., Jasani, M. K., Dalakos, T. G., Grieveson, P., and Buchanan, W. W. (1968) Quart. J. Med. 37, 393 (Clinical studies with an articular index for the assessment of joint tenderness in patients with rheumatoid arthritis)

Robertson, A. (1971) 'VII European Rheumatology Congress': abstract No. 45/4 (The metabolism of benorylate in healthy human volunteers)

- Glynn, J. P., AND Watson, A. K. (1972) Xenobiotica, 2, 339 (The absorption and metabolism in man of 4-acetamidophenyl-2-acetoxybenzoate (benorylate))

Ropes, M. W., Bennett, G. A., Cobb, S., Jacox, R., and Jessar, R. A. (1959) Ann. rheum. Dis. 18, 49 (Diagnostic criteria for rheumatoid arthritis) 
Rosner, I., Malhie, P., ANd Mottot, G. (1968) Thérapie, 23, 525 (Pharmacologie du 4-(acétamido) phenyl-2acétoxybenzoate (Win. 11,450))

Vialatel, C., AND Gaillon, R. (1968) Ibid., 23, 535 (Essais comparatifs du benzoate d'acétoxy-2-acétamidophényl 4 (Win. 11,450) de l'aspirine et du placebo en stomatologie)

Weill, J., Gaillon, R., Rendu, C., AND Lejeune, C. (1968) Ibid., 23, 541 (Un nouvel antipyrétique d'usage pédiatrique l'acétoxybenzoate 2-(acétamido) phényl 4)

Wootron, I. D. P. (1964) ‘Micro-Analysis in Medical Biochemistry', p. 116. Churchill, London 